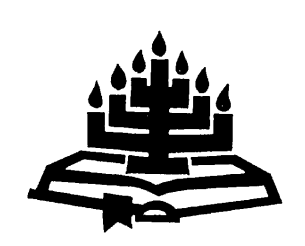

\title{
Paulus se gebruik van Psalm 68 in Efesiërs 4
}

\author{
L. (Bert) Floor \& Francois P. Viljoen \\ Skool vir Bybelwetenskappe en Bybeltale \\ Potchefstroomse Universiteit vir $\mathrm{CHO}$ \\ POTCHEFSTROOM \\ E-pos: sbbfpv@puknet.puk.ac.za \\ Ifloor@mweb.co.za
}

\begin{abstract}
Paul's use of Psalm 68 in Ephesians 4

The use of the Old Testament in the New Testament is one of the key issues in the field of intertextuality. Intertextual studies can be fascinating, but sometimes pose difficulties. Solutions are often less obvious. One difficult crux interpretum is found in Ephesians 4:8. Here the New Testament author makes a significant Christological application of Psalm 68:19. In its own context this Old Testament passage relates to the acceptance of (congratulatory) gifts by a victorious Israelite king. Ephesians 4:8, however, relates this passage to the provision of gifts by the victorious and ascended Christ. A comparison between these two verses immediately reveals certain differences. The question underlying this article therefore is: why does the New Testament citation differ on important issues from Psalms 68:19 in its Old Testament context, and what is the significance of these differences?
\end{abstract}

\section{Opsomming}

Paulus se gebruik van Psalm 68 in Efesiërs 4

Die gebruik van die Ou Testament in die Nuwe Testament is een van die wesenlike vraagstukke op die terrein van intertekstualiteit. Sodanige ondersoeke is fassinerend, maar gee soms ook aanleiding tot moeilike vraagstukke. Oplossings is dikwels nie voor die hand liggend nie. 'n Moeilike crux interpretum kom in Efesiërs 4:8 voor. Hier maak die Nuwe-Testamentiese skrywer 'n merkwaardige Christologiese interpretasie van Psalm 68:19. In sy eie konteks handel hierdie Ou-Testamentiese teks oor die aanvaarding van geskenke (van gelukwensing) deur die triomferende koning. Efesiërs 4:8 daarteenoor betrek hierdie gedeelte by die voorsiening van gawes deur die triomferende Christus wat opgevaar het. 'n Vergelyking tussen hierdie twee tekste toon onmiddellik merkwaardige 
verskille. Die kernvraag van hierdie artikel is dus waarom hierdie Nuwe-Testamentiese aanhaling in belangrike opsigte van Psalm 68:19 in sy Ou-Testamentiese konteks afwyk, en wat die betekenis van hierdie verskille sou wees.

\section{Inleiding}

In sy brief aan die Efesiërs skryf die apostel Paulus ${ }^{1}$ oor die gawes wat Christus in sy kerk uitdeel. Die charismatiese diens van elke gelowige in die kerk van Christus word breedvoerig deur die apostel beskryf in Efesiërs 4:7-16. Om te verduidelik op watter wyse Christus sy gawes uitdeel en hoe elke gelowige daarin mag deel, doen die apostel 'n beroep op die Ou Testament. Met 'n sitaat uit Psalm 68 maak Paulus duidelik dat die uitdeel van die charismata (genadegawes) verband hou met die heerskappy van Christus en met sy hemelvaart. Die skrywer van die brief aan die Efesiërs neem 'n strofe van 'n bekende psalm uit die Ou Testament en vorm dit tot 'n dogma vir die kerk van die Nuwe Testament. Dit vorm 'n leerstuk oor Christus se troonsbestyging en oor die belangrike leerstuk van die geestelike gawes. Dit is veral die wyse waarop Paulus met 'n frase uit die Ou Testament omgaan, wat baie vrae oproep. Kan 'n mens op hierdie manier met die Bybel omgaan? Mag 'n hedendaagse ekesegeet ook so eksegetiseer?

Hierbenewens kom die vraag op of Paulus dit bewus of meer onbewus gedoen het? Of anders gestel: het die apostel dit op grond van direkte beïnvloeding of op grond van indirekte beïnvloeding gedoen? Verder duik vrae soos die volgende op: het daar dalk 'n tradisie bestaan het wat hierdie interpretasie tot gevolg kon hê, en wat het die apostel beweeg om die verandering aan te bring?

Edgar (1962-63:62) het met verwysing na Paulus en die evangeliste se hantering van Ou Testament gekla oor hulle gebrek aan respek vir die konteks van die Ou-Testamentiese aanhalings.

Wanneer ondersoek ingestel word op watter wyse Paulus (en die evangeliste) met die Ou Testament omgaan, kom die terrein van intertekstualiteit aan die orde. Morgan (1985:5) bied 'n duidelike definisie hiervan: "Intertextuality is a term used by literary theorists in its broadest sense to designate the structural relation among two or more texts." Hierdie deeldissipline van Skrifverklaring "provides valuable insights and tools for the study of the Old Testament in the New" (Moyise, 2000:1516). 'n Aanverwante term wat ook gebruik word, is "inner-biblical exewas nie. Hierdie vraagstuk word elders beredeneer. Vergelyk daarvoor Floor (1995:1018). 
gesis" waarmee die verhouding tussen tekste en die gevolglike herinterpretasie van hierdie tekste ondersoek word (Keesmaat, 1994:31). 'n Verskeidenheid oorwegings kom aan die orde wanneer so 'n studie onderneem word, waaronder tekskritiek, hermeneutiek, eksegese, teologie en selfs kanoniese vrae (Taylor, 1991:319).

Hays (1989) wy 'n uitgebreide studie aan Ou-Testamentiese "echoes" in "outentieke" Pauliniese geskrifte (waaronder hy Efesiërs nie reken nie). Hy fokus op die metodologie en literêre analise van sodanige "echoes". Hy lê sewe kriteria aan waarvolgens die eggo's geïdentifiseer en ondersoek kan word ("availability, volume, recurrence, thematic coherence, historical plausibility, history of interpretation, satisfaction"2) (Hays, 1989:29-32). Op grond van 2 Korintiërs 3:17 ("waar die Gees van die Here is, is daar vryheid" - 1983-vertaling) kom hy tot die gevolgtrekking dat Paulus vry met die teks omgegaan het: hy het dit eerder metafories as letterlik gebruik (Hays, 1989:198). Hays is van mening dat Paulus aansluit by Joodse verklaarders van sy tyd wat met hulle interpretasie wou aantoon wat die woord van God vir hulle in hulle eie situasie beteken het.

Keesmaat (1994:29-54) sluit by Hays se kriteria aan in haar ondersoek van die transformasie van tradisie deur middel van intertekstualiteit. Sy gee aandag aan die eksodus-tradisie wat ge-eggo word in Romeine 8:14-30. Volgens haar is Paulus nie geïnteresseerd in regstreekse eksegese van Ou-Testamentiese tekste nie: hy probeer nie om die ou verhaal oor te vertel of 'n sistematiese eksegese van 'n teks te bied nie. Volgens haar gebruik Paulus die Ou-Testamentiese tradisie meer implisiet "on the level of echo or allusion" (Keesmaat, 1994:32). Volgens Morgan (1985:5) kan die verhouding tussen tekste op 'n verskeidenheid maniere voorkom: dit mag eksplisiet of implisiet wees, en bedoeld of onbedoeld. Die mees eksplisiete vorm van intertekstuele verhoudings is aanhalings, terwyl die mees implisiete voorkom as "allusions" of "echoes".

Fishbane (1985) bring tradisie aan die orde wanneer hy oor intertekstualiteit in Joodse geskrifte handel. Die herinterpretasie van tradisie

- "Availabilty": Was die voorgestelde bron beskikbaar vir die outeur?

- "Volume": Hoe uitgebreid kom die eggo in die teks voor?

- "Recurrence": Hoe dikwels word na dieselfde teks verwys?

- "Thematic coherence": Hoe goed pas die aanhaling / eggo in by gedagtegang van die nuwe teks?

- "Historical plausibility": Sou die lesers die gebruik van sodanige teks kon verstaan en aanvaar?

- "History of interpretation": Het ander lesers ook al sodanige eggo's opgemerk?

- "Satisfaction": Verhelder die teks die omliggende gedagtegang? 
(soos in die oorspronklike teks opgeteken) vind plaas wanneer dié teks toegepas word op 'n nuwe situasie. Dit het 'n metode tot gevolg waardeur traditum van die verlede in huidige traditio geïnkorporeer word om sodoende die traditium van opvolgende geslagte te word (Fishbane, 1985:18). Fishbane noem hierdie proses "inner-biblical exegesis". Die gevolg is dat dit wat in skriftelike vorm ontvang is, nooit identies is as dit wat verder oorgelewer word nie. Boyarin $(1990: 22,38,104)$ toon aan dat dit die manier is waarop tradisies in die Midrash getransformeer is en herleef het binne nuwe kontekste.

Daar bestaan verskil van mening oor wat presies onder "intertextuality" verstaan moet word. Standpunte is so uiteenlopend dat Porter (1997:7998) met die aanbeveling kom dat die term "intertextuality" voorlopig maar buite die geleerde diskussie gehou moet word. Moyise (2000:17) wil egter die gesprek aan die gang hou. Daarom het hy met die voorstel gekom dat die term "intertextuality" as 'n sambreelterm beskou moet word waaronder verskillende subkategorieë gerangskik kan word. Moyise onderskei die volgende kategorieë:

- "intertextual echo": "This approach views that echoes are faint traces of texts that are probably quite unconscious but emerge from minds soaked in the scriptural heritage of Israel" (Moyise, 2000:6);

- "dialogical intertextuality": "This approach views the action between the text and subtext to operate in both directions, to be true interaction, and it endeavours to find ways of describing the result of such interactions" (Moyise, 2000:17); en

- "postmodern intertextuality": "This approach acknowledges that it is not possible to secure meaning by defining (controlling) how a text interacts with a subject. Postmodern intertextuality is aiming to show that 'meaning' is always bought at a price and explores what that price is, in other words, meaning can only result if some interactions are privileged and others are silenced" (Moyise, 2000:17).

Moyise (2000:41) toon aan dat wanneer Ou-Testamentiese aanhalings in die Nuwe Testament voorkom, daar in baie gevalle sprake is van analogieë. As moontlike analogieë noem hy die volgende:

- "promise and fulfilment": 'n sprekende voorbeeld is die belofte in die saamgestelde aanhaling uit Maleagi 3:1 en Jesaja 40:3 wat volgens Markus 1:1-3 in vervulling gaan;

- "the veil lifted": Moses en sy sluier (Eks. 34:34) is die simbool van mense se verstand wat agter sluiers bedek is om nie die $\mathrm{Ou}$ Testament te verstaan nie (2 Kor. 3:14-16). Christus het die sluier kom wegneem sodat die Skrifte verstaan kon word; en 
- "written for our instruction": 'n beroep word op Ou-Testamentiese gedeeltes gedoen om bepaalde sake toe te lig (Matt. 19:1-22; 22:1540).

Moyise maak ten opsigte van hierdie aspek 'n waardevolle onderskeid. Tog sou dit sinvol wees om nog 'n belangrike onderskeid by te voeg. In die ondersoek van intertekstualiteit moet ' $n$ mens ook rekening hou met wat Smith (1975:183) die prefigurasie van die verlossingswerk noem, wat met die koms van Christus in vervulling gegaan het. Bruce (1959:68) gebruik ander woorde om dieselfde saak te beklemtoon as hy daarop wys dat "the New Testament interpretation of the Old Testament is not only eschatological, but also Christological".

Die vraagstukke by intertekstuele ondersoeke is talryk, terwyl die oplossings soms minder voor die hand liggend is. Efesiërs 4:8 is inderdaad so 'n moeilike crux interpretum binne hierdie navorsingsterrein.

\section{Metodologiese oorwegings}

Ten aanvang word die tekste van Psalm 68:19 en Efesiërs 4:8 met mekaar vergelyk om die spesifieke veranderings te identifiseer, waarna oorgegaan word tot 'n ondersoek van moontlike verklarings van hierdie veranderings. Na die beskrywing van 'n merkwaardige verklaring van Efesiërs 4:8 deur Marius Victorinus van Pettau word gesoek na verantwoordbare verklarings van die verskille.

As vertrekpunt word die tekste eers onderskeidelik in hulle eie kontekste ondersoek om hulle openbaringshistoriese plasing en belangrike teologiese motiewe te bepaal. Daarna word 'n verskeidenheid moontlike verklarings van die verskille ondersoek. Getuienis uit verskeie bronne word oorweeg, waaronder die Targum en die Midrash van Psalm 68. Die moontlikheid word ook ondersoek of Paulus hom by die rabbinistiese tradisie aangesluit het. Op grond van hierdie ondersoeke word gevolgtrekkings gemaak.

\section{3. 'n Vergelyking tussen Psalm 68:19 en Efesiërs 4:8}

Uit 'n vergelyking tussen Psalm 68:19 en Efesiërs 4:8 blyk dadelik 'n aantal verskille. (Vergelyk die tabel op die volgende bladsy.)

Die apostel gee nie 'n regstreekse aanhaling van Psalm 68:19 nie. Hy bring drie veranderings aan:

- Hy verander die handelende persoon, "U het opgegaan" (tweede persoon), na "Hy het opgevaar" (derde persoon); 
- Hy verander die rol van mense, "mense het vir U geskenke gebring" (mense is die gewers), na "Hy het gawes aan die mense gegee" (mense is die ontvangers); en

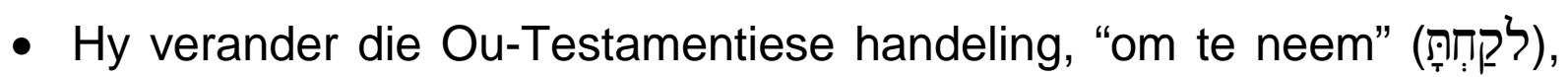
na "om te gee" ('€ $\delta \omega \kappa \in \nu)$.

\begin{tabular}{|c|c|}
\hline $\begin{array}{l}\text { Psalm 68:19 } \\
(18, \text { Heb.) (Masoreties) }\end{array}$ & $\begin{array}{l}\text { Efesiërs 4:8 } \\
\text { (United Bible Society 3) }\end{array}$ \\
\hline 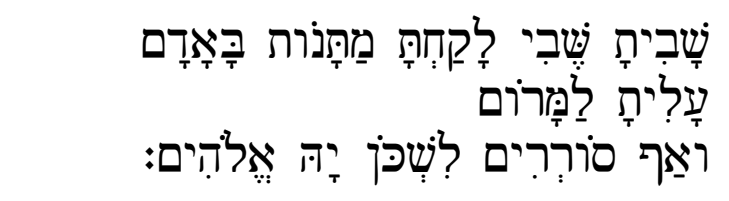 & 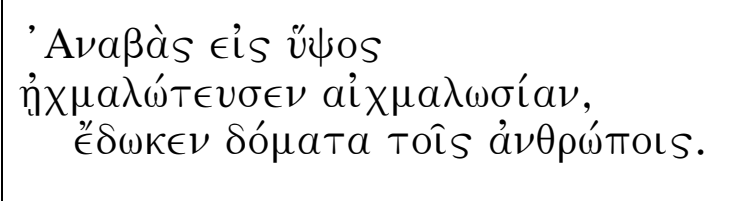 \\
\hline $\begin{array}{l}U \text { het krygsgevangenes wegge- } \\
\text { voer, mense het vir } U \text { geskenke } \\
\text { gebring, selfs dié wat teen } U \text { in } \\
\text { opstand was. Toe het } U \text { opge- } \\
\text { gaan na die hoogte. }{ }^{3}\end{array}$ & $\begin{array}{l}\text { Toe Hy na die hoogte opgevaar } \\
\text { het, het Hy krygsgevangenes } \\
\text { saamgeneem en gawes aan die } \\
\text { mense gegee. }\end{array}$ \\
\hline
\end{tabular}

Die belangrikste van hierdie drie veranderings is ongetwyfeld die laaste een. Kan dit sommer gedoen word? Is hier nie sprake van literatuurvervalsing nie? Hierdie artikel fokus op hierdie laaste verandering. Die vraag is waarom hierdie aanhaling so ingrypend van sy Ou-Testamentiese konteks verskil en wat die betekenis daarvan sou wees.

\section{4. 'n Merkwaardige verklaring uit die vierde eeu}

Die eksegese van Efesiërs 4:8 het 'n lang en interessante geskiedenis. Hierdie geskiedenis begin al in die vierde eeu na Christus. Daar is ' $n$ aantal geleerdes wat gepoog het om Efesiërs 4:8 te eksegetiseer (vgl. Floor, 1995:149). Eksegete kom telkens tot die gevolgtrekking dat hierdie 'n moeilike teks is om te verstaan.

In die geskiedenis van die eksegese is Marius Victorinus van Pettau (Petavio in Stiermarken, die huidige Slavonië waar hy biskop was) een van die eerste eksegete wat hierdie teks van kommentaar voorsien het (vgl. Erdt, 1980:10; Hadot, 1971:24). Victorinus (gebore in 285 in Afrika) was die eerste eksegeet wat in Latyn kommentare op verskillende Bybelboeke geskryf het. Sy kommentaar op Paulus se brief aan die Efesiërs is bekend. In die kritiese apparaat van Nestle-Aland (27) word van die kommentaar van Victorinus weergegee met die sogenaamde 
Siglum MVict. wat herhaaldelik onder die teks van Efesiërs voorkom. Hierdie eksegeet uit die oudheid gee in sy kommentaar op die brief aan die Efesiërs uitvoerig aandag aan Paulus se hantering van Psalm 68:19 in Efesiërs 4:8. Hy noem hierdie aanhaling 'n groot misterie. Hy wou graag breedvoerig op 'n bespreking van hierdie moeilike teks ingaan, maar wou, wanneer God dit toelaat, dit later doen (hy was egter toe al 80 jaar oud).

Van Victorinus kan ons leer hoe ons so 'n moeilike teks nié moet probeer verklaar nie. Hy gebruik die metode om Skrif met Skrif te vergelyk en gebruik dan Johannnes 3:3 ("As iemand nie opnuut gebore word nie, kan hy die koninkryk van God nie sien nie") en 3:6 ("Wat uit die mens gebore is, is mens; en wat uit die Gees gebore is, is gees") om hierdie teks van Paulus te verklaar. Sy bevinding is dat Christus na die hemel opgevaar het om die siel van die mens van sy stoflike liggaam te bevry. 'n Mens moet gees word om na die hoëre wêreld te kan terugkeer (Meijer, 2001: 220-221). Dit is duidelik dat Victorinus deur die Neo-Platoniese wysbegeerte beïnvloed is om die teks op so 'n manier te verklaar. Victorinus het hierdie verkeerde vertrekpunt gebruik in sy eksegese van die teks.

In die tyd van die Reformasie is daar ook aan die eksegese van die teks aandag gegee (Calvyn, 1972:55-56; Bucer, 1527:86), maar daar is nie 'n antwoord gebied waarom die apostel tot so 'n ingrypende verandering in sy aanhaling gekom het nie.

In die vorige eeu was dit Strack en Billerbeck (1927:596-598) wat vir die eerste keer 'n antwoord op die vraag gebied het deur Efesiërs 4:8 vanuit die Talmoed en Midrasj te verklaar. Hierdie insig verdien ernstige oorweging by die ondersoek van die intertekstualiteit van hierdie teks (vgl. Floor, 1979a:78).

\section{Die onderskeie kontekste van Psalm 68:19 en Efesiërs 4:8}

Om groter duidelikheid te kry oor die aard van die veranderings wat Paulus aangebring het, is dit nodig om die historiese konteks, belangrikste motiewe en doel van van die tekste onderskeidelik te ondersoek.

\subsection{Psalm 68:19}

Wanneer dit by die eksegese van Psalm 68 kom, word dit gou duidelik waarom hierdie psalm as een van die moeilikste psalms uit die hele Psalmboek beskou word. Sowat vyftig jaar gelede het Iwry (1952:161) al opgemerk: 
There is scarcely another psalm in the entire Psalter which has produced as many exegetical differences amongst scholars as Psalm 68. Not only does it swarm with obscure expressions and phrases, but the psalm as a whole has hitherto defied every critical attempt at analysis, interpretation and dating.

'n Bekende verklaring is dié van Albright (1950-51:7), naamlik dat Psalm 68 bestaan uit 'n reeks incipits, of te wel beginfrases van verskeie afsonderlike gedigte wat by vroeëre geleenthede tot stand gekom het. $\mathrm{Hy}$ dateer die eventuele versameling van die incipits in die tyd van Salomo of kort daarna. Hierdie verklaring bied 'n moontlike antwoord op die skynbare afwesigheid van 'n gedagte-eenheid in dié psalm.

Psalm 68 is ook moeilik om vormhistories te klassifiseer. In 'n sekere sin is dit 'n gemeenskaplike danksegging, aangesien dit die oorwinning wat Jahwe vir sy verdrukte volk bewerk het, vier. Dié psalm is egter ook 'n historiese himne wat verwys na die verlossing uit Egipte en die Here se voorsiening aan sy volk tydens hulle moeilike deurtog van die woestyn. Hierbenewens bevat Psalm 68 ook elemente van 'n prosessionele liturgie van die tempel in Jerusalem (bv. vers 24 en 29) (Taylor, 1991: 332).

Hierdie vermenging van motiewe maak dit moeilik om die gedagtegang van die psalm te volg. Die oorkoepelende boodskap is wel dat God geprys moet word. Hy het sy volk in die verlede gered en versorg; daarom kan hulle ook vir die hede en toekoms vertrou dat Hy hulle sal versorg. In sy geheel het Psalm 68 te doen met die oorwinningstog van God. Hy het oor sy vyande geseëvier. Die oorwinningstog verwys na die gebruik in antieke tye dat 'n oorwinnende vors die vyande wat hy gevange geneem het, saam met al die buit wat hy verower het en wat hy van die oorwonnenes ontvang het, in 'n triomftog vooruitgegaan het (Roberts, 1990:115). So teken Psalm 68 God as die oorwinnaar oor sy vyande. Hy het hulle gevange geneem en baie buit van hulle ontvang. In sy triomftog trek Hy dan vanaf Sion vooruit na die hoogte van die tempelberg.

Benewens die feit dat hierdie Psalm in sy geheel reeds so moeilik is om te verklaar, roep vers 19 nog meer vrae op (Van der Ploeg, 1971:391). Navorsers se vertolking van hierdie teks is baie uiteenlopend. Die groot vraag is waarna die vers verwys. Verskeie opsies is deur eksegete voorgestel, waaronder die volgende:

- Die digter verwys na Moses op die berg Sinaï (Eks. 20:1-17) waar hy die Dekaloog ontvang het en as 'n geskenk aan die volk Israel gegee het (Pokorny, 1992:170; Roberts, 1990:114). 
- Psalm 68:19 word teen die agtergrond van Numeri 8:6-19 gelees. Daar word vertel dat die Leviete uit die midde van die volk geneem is om God op 'n besondere wyse te dien. In hulle diens is hulle as 'n gawe aan die volk gegee (Smith, 1975:187).

- Psalm 68:19 roep die beeld op van Dawid wat die ark na Jerusalem neem soos in 2 Samuel 6:12-19 beskryf is (Wilson, 1978:85; Holwerda, 1950:162). In die persoon van die koning het God na Sion opgegaan in triomf oor sy vyande, terwyl hy van onderdanige mense geskenke van dank en eer ontvang.

Binne die direkte konteks van vers 16-19 blyk 'n verklaring van 'n Israelitiese koning wat vol vertroue 'n stryd tegemoet gaan, omdat die Here voorheen vir sy volk ingetree het met die uittog en oorwinning, na die mees aanvaarbare. In 'n daaropvolgende oorwinning het die koning sy gevangenes in 'n triomftog gelei, terwyl sy onderdane sy terugkeer met geskenke vier (Taylor, 1991:323).

\subsection{Efesiërs 4:8}

In Efesiërs 4:7 verduidelik die apostel aan sy lesers dat Christus as Here (Kurios) aan elke gelowige 'n charis (gawe) gee. Die Griekse woord charis (genade) het hier eerder die betekenis van charisma (genadegawe) (Gnilka, 1971:206; Schnackenburg, 1982:178). Die vraag wat deur die eerste lesers van die brief gevra kon word, is of Christus wel oor die charismata beskik het en waar Hy dit vandaan gekry het? Om die moontlike vraag vir sy lesers te beantwoord en om krag te gee aan sy stelling, gebruik Paulus in 4:8 'n aanhaling uit Psalm 68:19. Daarna volg in 4:9-11 'n kort verklaring van hierdie aanhaling in die vorm van 'n Christologiese toepassing van die Ou-Testamentiese vers. Hiervolgens vind die "opgaan" van Psalm 68:19 sy vervulling in die opstanding en hemelvaart van Christus, wat veronderstel dat Hy eers neergedaal het in sy menswording. Met sy hemelvaart het $\mathrm{Hy}$ aan die kerk ' $\mathrm{n}$ verskeidenheid gawes gegee. Omdat Paulus die goddelike oorsprong van die geestelike gawes aan die kerk verklaar, skryf hy in Efesiërs 4:8 oor die "gee" van gawes in plaas van die "ontvang" daarvan soos in Psalm 68:19.

Die vraag is nou op grond waarvan Paulus hierdie verandering kon aanbring en waarom hy die vers so geïnterpreteer het. Die antwoord op hierdie vraag hou belangrike hermeneutiese en teologiese implikasies in.

\section{Moontlike verklarings}

Om te verklaar waarom Paulus hierdie verandering aangebring het, is daar 'n aantal moontlikhede om te oorweeg. 


\subsection{Aanhaling uit die Septuaginta}

'n Logiese vraag sou wees of Paulus nie eerder uit die Septuaginta as uit die Masoretiese teks aangehaal het nie. Dit was immers die gebruik by talle Nuwe-Testamentiese skrywers. Wanneer Psalm 68 [67]:19 in die Septuaginta ondersoek word, blyk dit dat dit nie die geval was nie. Die tersaaklike deel van die vers in die Septuaginta lui:

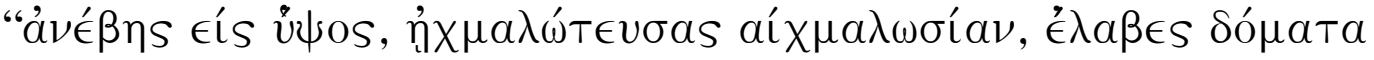 $\dot{\epsilon} \nu \stackrel{\alpha}{\nu} \theta \rho \omega \dot{\pi} \pi \omega "$ ( $U$ het na die hoogte opgevaar, $U$ het gevangenes meegevoer, $U$ het geskenke onder die mense ontvang).}

Hoewel daar enkele afwykings van die Masoretiese teks is, stem die Septuaginta met die Masoretiese teks op dié belangrike punt ooreen. Die Septuaginta gebruik "U het ontvang" ('́ $\lambda a \beta \epsilon S)$ wat ooreenstem met die

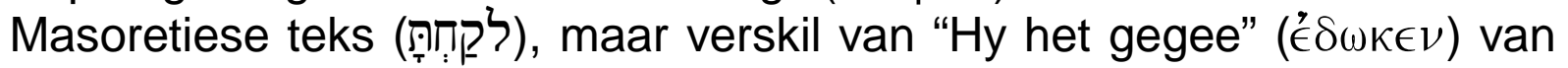
Efesiërs 4:8.

Hierdie moontlikheid bied dus nie 'n oplossing vir die probleem nie

\subsection{Foutiewe aanhaling}

Sommige navorsers is van mening dat Paulus eenvoudig gefouteer het in sy gebruik van die Ou Testament. Richardson (1958:203) skryf byvoorbeeld dat Efesiërs 4:8 'n "misquoting" is van Psalm 68:19. Op 'n soortgelyke manier merk Fitzmyer (1960-61:325) op: "Here Paul completely disregards the original context of the Psalm."

So ' $n$ fel oordeel is egter onvanpas. Die verandering lei nie tot 'n teenstrydigheid nie. Dit is eerder 'n kontekstualisering van die Ou Testament om die voller betekenis van die Messiaanse era mee te beskryf. Daarbenewens impliseer so ' $n$ fel oordeel ' $n$ hedendaagse vereiste vir die gebruik van 'n aanhaling wat onbekend was in die tyd van antieke geskrifte (Taylor, 1991:324).

\subsection{Aanhaling van 'n vroeg-Christelike himne}

Nuwe-Testamentiese skrywers het dikwels na credo's of himnes verwys. Voorbeelde daarvan kom op talle plekke in die Nuwe Testament voor (Viljoen, 1990:8). In die lig van hierdie verskynsel was dít Hodge (1964:215) se verklaring dat Paulus van so 'n vroeg-Christelike himne gebruik sou maak.

In die lig van die duidelike ooreenkoms van Efesiërs 4:8 met Psalm 68 is die moontlikheid van 'n ander buite-Bybelse himne egter onwaarskynlik. 


\subsection{Aanhaling uit die geheue}

Uit die aard van destydse omstandighede was Ou-Testamentiese tekste nie altyd geredelik beskikbaar nie. Die gevolg is dat Kerkvaders destyds sekere tekste soms memoriter aangehaal het (Taylor, 1991:325). Dit sou uiteraard lei tot sekere diskrepansies met die oorspronklike teks.

Die vraag is of Paulus in Efesiërs 4:8 dalk ook uit sy geheue aangehaal het - iets wat die diskrepansie sou kon verklaar. So 'n verklaring is egter onwaarskynlik. Die verandering is daarvoor te opvallend en doelbewus.

\subsection{Aanhaling uit die Aramese vertaling}

Die moontlikheid bestaan ook dat Paulus van die Aramese (parafraserende) vertaling (Targoem) van die teks gebruik gemaak het vir sy aanhaling.

In die Targoem van Psalm 68:19 kom hierdie verandering van "neem" na "gee" inderdaad voor. In Afrikaans vertaal lui dit soos volg:

U het opgevaar na die hemel, dit is Moses die profeet.

$U$ het gevangenes meegevoer;

$U$ het die woorde van die Tora geleer

en hulle as 'n geskenk aan die mensekinders gegee".

Dit blyk dus dat sodanige lesing van Psalm 68 destyds ook buite die Nuwe Testament voorgekom het. Dit is onwaarskynlik dat die NuweTestamentiese bewoording ' $n$ invloed op die Targoem sou gehad het, as die aard van die Christen-Joodse polemiek van die vroeë Christelike tyd in aanmerking geneem word. Dit is egter wel 'n moontlikheid dat 'n teksvorm van Psalm 68:19 wat die werkwoord "gee" in plaas van "ontvang" gehad het, 'n invloed op die Nuwe-Testamentiese teks sou hê.

Die vraag ontstaan waar hierdie verandering in die Targoem vandaan kom. In die Joodse literatuur is daar voorbeelde dat die werkwoord "neem" in bepaalde tekste verklaar word as "neem om te gee". Schlier (1968:191) beredeneer hierdie verskynsel en toon aan hoe dit ook met Eksodus 25:2 en 2 Konings 17:3 gedoen is. Dit stem ooreen met die destydse gebruik van Joodse verklaarders om tekste te aktualiseer in nuwe geskrifte (Boyarin, 1990:22; Fishbane, 1985:18). Die betekenis van die Hebreeuse laqach (ontvang om te gee) is vir sy beredenering van deurslaggewende belang. So het Moses inderdaad ook die wet (tafels) ontvang en daarna aan die volk gegee (Roberts, 1963:80).

In die Joodse literatuur uit die tyd van die Nuwe Testament word Psalm 68:19 byna altyd betrek op Moses wat die berg Sinai opgegaan het om die Dekaloog te ontvang (Dormandy, 1998:207; Roberts, 1990:114). Die 
vermelding van die berg Sinai in Psalm 68:18 het sekerlik hiertoe aanleiding gegee. In die Targoem van Psalm 68 word die triomftog van die oorwinnaar en die gevangeneming van die gevangenes toegepas op Moses wat die berg bestyg het om die wet te leer ken en dit aan die mense as gawe te skenk. In hierdie tradisie kom dan die merkwaardige vervanging van "gawes ontvang" met "gawes skenk" voor (Dormandy, 1998:206).

Dit is opvallend dat hierdie variante lesing ook in die Pesjitta voorkom. Hoewel daar nie eenstemmigheid onder navorsers is nie, word redelik algemeen aanvaar dat hierdie vertaling in Siries een van die oudste vertalings van die Ou Testament was. Die meeste manuskripte van die Pesjitta (vertaal in Afrikaans) lui:

$U$ het na die hoogte opgevaar; en $U$ het gegevangenes weggevoer; en $U$ het geskenke aan die seuns van die mens gegee (volgens Walter, 1980:55).

Die feit dat die Pesjitta gedurende die eerste eeu ontstaan het, laat die vraag na vore kom of dit reeds vir Paulus beskikbaar was (Taylor, 1991:334). Dit is egter moeilik om vas te stel. Wat wel duidelik is, is dat so 'n variante lesing van Psalm 68 in omloop was.

\subsection{Midrasj en pesjer}

'n Ander moontlikheid is dat die apostel gebruik gemaak het van die algemene tegnieke van die vroeë Joodse hermeneutiek, naamlik die sogenaamde midrasj- of pesjer-metodes.

'n Midrasj is 'n rabbynse vorm van Skrifverklaring wat ongeveer aan die begin van die Christelike jaartelling by die rabbyne in swang was. So 'n Skrifverklaring is allegories van aard. 'n Midrasj kan omskryf word as 'n praktiese, verhalende, aktualiserende vorm van Skrifverklaring (Bijlsma, 1961:103; Fishbane, 1985:18). Voorbeelde van sodanige midrasj kom voor in 1 Korintiërs 10:4 (die geestelike voedsel en drank van die Israeliete in die woestyntog word gelykgestel met Christus) en Galasiërs 4:21-31 (Hagar en haar seun word allegories gelykgestel aan die Jode wat nie in Christus wil glo nie, en Sara en haar seun aan Christene). Volgens die Skrifgeleerdes het elke ware midrasj in wese die aktualisering van 'n teks geïmpliseer (vgl. Bijlsma, 1961:103; Boyarin, 1990:38).

Dit is ook moontlik dat Paulus gebruik gemaak het van die pesjer-metode van Skrifverklaring. Pesjer is verwant aan 'n Aramese woord wat uitleg of interpretasie beteken. Hierdie pesjer-metode van Skrifaanhaling en Skrifverklaring was in die Qumran-gemeenskap gebruiklik. Hierdie 
metode is nou verwant aan die midrasj-metode. Daar word egter 'n nog sterker verband gelê tussen die teks en bepaalde gebeurtenisse uit die tyd van die skrywer (Floor, 1979a:56). Deur middel van die pesjermetode sluit die Skrifverklaarder homself regstreeks in by die vervulling van 'n bepaalde profesie (Wright, 1997:115).

Die mense van Qumran het die oortuiging gehad dat die Ou Testament sy vervulling sou vind in 'n nuwe reeks gebeurtenisse. Op hierdie punt is daar, soos Versteeg (1977:17) en Wright (1997:115) dit stel, 'n groot ooreenkoms tussen interpretasies van die Ou Testament in die Nuwe Testament en die pesjer van Qumran. Moody Smith (1972:36-37) huldig ook die siening dat Paulus nader aan Qumran se manier van OuTestamentiese Skrifverklaring staan as aan die rabbyne se metode.

Ellis (1957:149) noem vier eienskappe tipies van die midrasj en pesjer:

- die kombinasie van verskeie Ou-Testamentiese aanhalings om 'n enkele nuwe bewysteks te vorm;

- die aanpassing van Ou-Testamentiese grammatika om die nuwe konteks en toepassing te pas;

- 'n seleksie van ander beskikbare Targoemim; en

- die skepping van ad hoc-interpretasies.

Hierdie tegnieke is deur die skrywer gebruik om uitdrukking te gee van die wyse waarop hy die teks in 'n nuwe konteks verstaan en toepas.

In 'n midrasj (wat moontlik op hierdie variante lesing van die Targoem gebaseer is), kom die verandering van "neem" na "gee" ook voor. In die midrasj van Psalm 68 paragraaf 11 (160a) staan:

$U$ het gawes ontvang vir die mense,

dit is die tora wat as 'n geskenk aan die Israeliete gegee is

(vgl. Strack \& Billerbeck, 1927:596).

Dit is daarom 'n sterk moontlikheid dat Paulus kennis gedra het van sodanige midrasj op Psalm 68 wat gebaseer is op so 'n variante teks van die Targum (Smith, 1975:181-189). Dit is immers opmerklik dat die apostel se aanhaling van Psalm 68:9 op 'n soortgelyke manier as die Targoem en midrasj van die Masoretiese teks verskil.

Die argument dat Paulus by hierdie Joodse verklaringsmetode aansluiting gevind het, hou groot meriete in. Dit bied 'n logiese verklaring vir die verandering van die teks van Psalm 68:19 en toon die historiese en kulturele wortels van die verklaringsmetode van die destydse Jode. 


\section{Paulus se hantering van Psalm 68:19 in sy brief}

Om die vraag te beantwoord waarkom die apostel hierdie verandering in die teks aangebring het, is dit sinvol om eers die vraag te beantwoord waarom Paulus hierdie Psalmvers aangewend het om oor die legitimiteit van die charismata in die gemeente te skryf.

Daarvoor sluit Paulus by die gedagte van oorwinning in Psalm 68 aan. Psalm 68 handel oor die triomftog van God (en koning) as oorwinnaar. In Efesiërs 4 pas Paulus dit toe op Christus (Dormandy, 1998:206). Jesus het as mens neergedaal aarde toe. Dat $\mathrm{Hy}$ in sy lyding en sterwe die oorwinning behaal en die vyande gevange geneem het, kan in sy verheerliking en hemelvaart gemerk word. Noudat Hy oorwin en die hemelse heerlikheid betree het, beskik $\mathrm{Hy}$ as Oorwinnaar oor die mag om gawes aan sy volgelinge uit te deel.

Die apostel wys in Efesiërs op die besondere posisie van die verhoogde Christus. Hy is die verhoogde Kurios (Here), die Oorwinnaar oor alle dinge. As verhoogde Kurios is Christus die Gewer van gawes (charismata) wat sy gemeente nodig het om te kan bestaan en te groei.

By wyse van 'n midrasj illustreer Paulus dit aan die hand van 'n gedeelte van 'n lied uit die Psalmboek van die Joodse volk. Soos Christus opgevaar het, so spreek dié psalm van 'n opgaan en soos Christus die oorwinning behaal het, spreek dié psalm van 'n gevangeneming van vyande - 'n handeling wat die oorwinning aandui. Christus is die Gewer van gawes soos die psalm ook van gawes spreek, al is dit die ontvangs van gawes.

Uit Paulus se hantering van die Ou-Testamentiese teks word die indruk geskep dat die apostel met die Targoem se toepassing van dié psalm op Moses bekend was. Die nuwe is egter dat Paulus in sy hantering van ' $n$ Ou-Testamentiese lied tot 'n Christologiese verklaring daarvan kom (Taylor, 1991:336).

In ooreenstemming met hierdie tradisie word Christus as die "meerdere" Moses in Efesiërs 4:8 geteken. Die magtige reddingsdaad van God is pas in die heilsgebeure deur Jesus ten volle verwerklik. Daarom was dit nie Moses wat God se eintlike gawe in die vorm van die Tora (wet) gegee het nie. Christus het dit egter gedoen met die charismata wat Hy in die kerk aan elke gelowig skenk (Barth, 1974:472-477). 


\section{Die Joodse Pinksterfees}

Tog verklaar dit nog nie volledig waarom die apostel Paulus Psalm 68:19 gebruik het om die betekenis van Christus se hemelvaart vir die kerk te verduidelik nie.

Paulus is blykbaar deur rabbinistiese tradisies beïnvloed in sy hantering van die teks. Die Joodse Pinksterfees is 'n sterk moontlikheid. Die Pinkstergebeure het Paulus diep geraak. Dit blyk baie duidelik uit sy brief aan die Efesiërs (Viljoen, 1990:136). Roberts (1984:139) het aangetoon hoe die Joodse berakah-gebede 'n grondmotief in die brief vorm. Meer as enige ander Nuwe-Testamentiese brief het Efesiërs die aard en vorm van so 'n gebed (De Klerk, 2002:2). Berakah-gebede is tydens die Joodse Pinkstertyd gebid en vorm die agtergrond van hoofstukke 1-3 van hierdie brief. Die hele brief aan die Efesiërs is gebaseer op die Pinkstergebeure (Roberts, 1984:139).

In die tyd van die Nuwe Testament het daar 'n verskuiwing in die betekenis van die Joodse Pinksterfees plaasgevind. Die fees ter gedagtenis aan die gebeure by die Sinai het verskuif na 'n fees ter herinnering aan die uitstorting van die Heilige Gees op Pinksterdag (Floor, 1979b:27; Van 't Goudoever, 1969:71).

Tydens die Joodse Pinksterfees is nie alleen Eksodus 19 gelees nie, maar ook Psalm 68 (Gnilka, 1971:208; Taylor, 1991:323). Teen hierdie agtergrond word Efesiërs 4 duideliker. Die Pinkstergebeure, en wat daaragter aan Joodse tradisie lê, het Paulus blykbaar op die gedagte gebring om in sy brief aan die Efesiërs ook 'n verband aan te dui tussen Psalm 68 en die gawes wat op Pinkster ryklik geskenk is en aan die kerk belowe is.

Hierdie moontlikheid word bevestig deur die gedagtesentrum van die berakah-gebed in Efesiërs 1:3-3:21. Jordaan (1990:51) toon hierdie sentrum aan as die geloofsbelydenis in Efesiërs 1:20-23. Hierdie belydenis handel oor die verheerliking van Christus as Hoof van die kerk en die heil wat hierdie feit vir die kerk inhou (Jordaan, 1990:53). Op hierdie belydenis is die paraklese van die brief (Efesiërs 4:1-6:20) gefundeer (Jordaan, 1990:59). Die verheerlikte Christus gee sy gawes aan die kerk (Efesiërs 4:8). Dit sluit aan by die Pinkstergebeure.

\section{Van lied na dogma}

In verse 9 en 10 van Efesiërs 4 word die enkele gedagte van die triomtog na omhoog op die Christusgebeure betrek. Die dogma van die hemelvaart van Christus en die leer van die gawes van die Gees as vrug van Christus se verhoging word in Efesiërs kanonies vasgelê. Die lied 
van Psalm 68 kristalliseer uit in die leer. Op sy beurt word hierdie leer weer deur die Gees by wyse van die lied by die mens vasgelê (Ef. 5:1821 - vgl. Viljoen, 2001:438). Sodoende word die lied 'n effektiewe onderrigmiddel waarmee die dogma vasgelê word (De Klerk, 2002:2,17). Met hierdie flits na 'n bekende lied-motief kon meer bereik word as met baie ander woorde (vgl. Viljoen, 2002:87). Dit kan as voorbeeld vir vandag dien wanneer daar besin word oor die funksionaliteit van die kerklied, veral ten opsigte van kerugmatiese en liturgiese modaliteite soos deur Kruger (2002:19-43) onderskei.

Lied (Ou Testament) en dogma (Nuwe Testament) reik mekaar die hand in Efesiërs 4. Die kerk sing wat hy bely, die geloof word uitgesing. Die dogma word deur die lied geartikuleer en geaktualiseer. Dogma word in en deur die lied gevorm. "Op God se doen en dade volg lied en lof in belydenis" (Bingle, 2000:52). So word die lied gebruik as die articulus fidei (verwoording van die geloof) (Huisamen, 1997:53).

Die vroeë kerk het die gebeure wat Paulus in Efesiërs 4:8-10 beskryf, in 'n pragtige himne tot uitdrukking gebring soos in 1 Timoteüs 3:16 opgeteken (Van Rensburg, 1989:83; Versteeg 1971:136; Zimmermann 1968:208):

As mens het Jesus in die wêreld gekom, deur die Gees is bevestig dat die reg aan sy kant is,

Aan die engele het Hy verskyn;

Aan die heidennasies is Hy verkondig,

In die hele wêreld is Hy geglo,

En in heerlikheid is Hy opgeneem.

\section{Gevolgtrekkings}

Die beskuldiging dat Paulus in Efesiërs slordig met die teks van Psalm 68 omgegaan het, is nie geldig nie. Die oorsprong van die verandering van "gee" na "neem" is nie in Efesiërs 4:8 te vind nie. Dit is egter geleë in 'n variante lesing met 'n ou geskiedenis soos wat uit die Targoem, Midrasj en Pesjitta blyk. Hierdie variante lesings was blykbaar goed bekend, veral in rabbinistiese kringe.

Hierbenewens sou dit anakronisties wees om moderne navorsingsmetodes te gebruik om Paulus se hantering van 'n aanhaling te kritiseer. Binne die destydse Joodse (Midrasj-Pesjer) hermeneutiek was dit legitiem om die teks op 'n nuwe situasie toe te pas. Die Jode het dit gedoen en ander Nuwe-Testamentiese skrywers ook. In die lig hiervan was dit nie Paulus se bedoeling om die Ou-Testamentiese konteks van Psalm 68 te ontken nie. Dit was ook nie sy bedoeling om dit as die 
enigste vervulling van die teks te bied nie. Hy trek bloot 'n analogie tussen die gebeure

Volgens Psalm 68:19 het God Sion opgegaan as 'n triomferende koning, waardig om geskenke te ontvang vir sy oorwinning. Volgens Efesiërs 4:8 het Jesus ook opgevaar na die hemelse Sion as die triomferende Here wat dan gawes aan sy kerk gegee het. Psalm 68 voorsien die patroon vir Efesiërs 4:8.

Volgens die kategorisering van Moyise (2000:37) het ons in Efesiërs 4 met 'n "intertextual echo" uit Psalm 68 te doen. Dit is ook gepas om te praat van ' $n$ analogie tussen die tekste (Moyise, 2000:41). Of dit egter presies inpas by een van die drie katergorieë wat Moyise (2000:41) onderskei ("promise-fulfilment", the veil lifted" en "written for our instruction") is nie onproblematies nie. Miskien is dit meer vanpas om te praat van 'n Christologiese perspektief (soos Smith, 1975:183 en Bruce, 1959:68 dit noem), wat Paulus op Psalm 68 bied.

\section{Bibliografie}

ALBRIGHT, W.F. 1950-1951. A catalogue of early Hebrew lyric poems (Psalm LXVIII). Hebrew Union College Annual, 23:26-38.

BARTH, M. 1974. Ephesians; Translation and commmentary on chapters 4-6. New York : Doubleday.

BIJLSMA, R. 1961. De Septuaginta en de hermeneutiek van de Bijbel. Woord en Wereld, 5:89-103.

BINGLE, J.P. 2000. Die verhouding tussen openbaring, dogmavorming en doksauiting in die liturgiese lied. Potchefstroom : PU vir CHO. (Th.M.-verhandeling.)

BOYARIN, D. 1990. Intertextuality and the meaning of the Midrash. Bloomington : Indiana University Press.

BRUCE, F.F. 1959. Biblical exegesis in the Qumran texts. Exeter : Paternoster.

BUCER, M. 1527. Epistola D. Pauli ad Ephesos. Argentorati p. A 6 recto. Strassbourg : Pluviers.

CALVYN, J. 1972. Uitlegging van de Zendbrieven van Paulus: Efeziërs. (Vert. A.M. Donner.) Goudriaan : De Groot.

DE KLERK, B.J. 2002. Lofliedere - basisteoretiese elemente uit Efesiërs 1:3-14. In die Skriflig, 36(1):1-18.

DORMANDY, R. 1998. The ascended Christ and his gifts. The Expository Times, 109:206-207.

EDGAR, S.L. 1962-63. Respect for context in quotations from the Old Testament. New Testament Studies, 9:55-62.

ELLIS, E.E. 1957. Paul's use of the Old Testament. Grand Rapids : Eerdmans.

ERDT, W. 1980. Marius Victorinus Afer, der erste latinische Paulus-kommentator. Studien zu seinen Pauluskommentaren im Zusammenhang der Widerentdeckung des Paulus in der abendländischen Theologie des 4. Jahrhunderts. Frankfurt am Main : Lang.

FISHBANE, M. 1985. Biblical interpretation in ancient Israel. Oxford : Clarendon.

FITZMYER, J.A. 1960-1961. The use of explicit Old Testament quotations in Qumran literature and in the New Testament. New Testament Studies, 7:297-333. 
FLOOR, L. 1979a. Eksegese en prediking by Paulus. Amsterdam : Bolland.

FLOOR, L. 1979b. Hy wat met die Heilige Gees doop. Pretoria : NG Kerkboekhandel.

FLOOR, L. 1995. Efeziërs. Eén in Christus (CNT). Kampen : Kok.

GNILKA, J. 1971. Der Epheserbrief. (Herders Theologisches Commentar zum Neuen Testament.) Freiburg/Basel/Wien : Ruprecht Verlag.

HADOT, P. 1971. Marius Victorinus. Recherches sur sa vie et ses oeuvres. Paris : Etudes Augustiniennes.

HAYS, R.B. 1989. Echoes of Scripture in the letters of Paul. New Haven : Yale University Press.

HODGE, C. 1964 [1856]. A commentary on the Epistle to the Ephesians. London : Banner of Truth.

HOLWERDA, B. 1950. Tot de dag aanlicht. Goes : Oosterbaan \& Le Cointre.

HUISAMEN, E. 1997. Kom ons sing die kerk weer vol. Kaapstad : Lux Verbi.

IWRY, S. 1952. Notes on Psalm 68. Journal of Biblical Literature, 71:161-165.

JORDAAN, G.J.C. 1990. Die verhouding tussen indikatief en paraklese in Efesiërs. In die Skriflig, 24(1):49-69.

KEESMAAT, S.C. 1994. Exodus and the intertextual transformation of tradition in Romans 8:14-30. Journal for the Study of the New Testament, 54:29-56.

KRUGER, D. 2002. Die funksionaliteit van die laat twintigste-eeuse kerklied. In die Skriflig, 36(1):19-43.

MEIJER, J.A. 2001. Marius Victorinus Afer. Portret van een pionier. (In Van Houwelingen, P.H.R., Van de Kamp, H.R. \& Meijer, J.A., red. Exeget(h)isch. Feestbundel voor prof. dr. J. van Bruggen. Kampen : Kok. p. 206-228.)

MOODY SMITH, D. 1972. The use of the Old Testament in the New. (In Moody Smith, D., ed. The use of the Old Testament in the New and other essays. Studies in honor of W.F. Stinespring. London: Hamish Hamilton. p. 36-37.)

MORGAN, T.E. 1985. Is there an intertext in this text? Literary and interdisciplinary approaches to intertextuality. American Journal of Semiotics, 3/4:1-40.

MOYISE, S. 2000. Intertextuality and the study of the Old Testament in the New. Sheffield : Academic Press.

POKORNY, P. 1992. Der Brief des Paulus an der Epheser. Theologischer Handbuch zum Neuen Testament, 10 \& 11. Leipzig : Evangelische Verlaganstalt.

PORTER, S.E. 1997. The use of the Old Testament in the New Testament: A brief comment on method and terminology. (In Evans, C. \& Sanders, J.A., eds. Early Christian interpretation of the Scriptures of Israel. Investigations and proposals. [JSNT Supplementum 5. 148 Studies in Scripture in early Judaism and Christianity.] Sheffield : Sheffield Academic Press. p. 79-96.)

RICHARDSON, A. 1958. An introduction to the theology of the New Testament. London : SCM.

ROBERTS, J.H. 1963. Die opbou van die kerk volgens die Efese-brief. Groningen : V.R.B.

ROBERTS, J.H. 1984. Die gevangenskapsbriewe (In Du Toit, A.B., red. Handleiding by die Nuwe Testament. Band V. Pretoria : N.G. Kerkboekhandel. p. 114-157.)

ROBERTS, J.H. 1990. Die brief aan die Efesiërs. Kaapstad : N.G. Kerk-Uitgewers.

SCHLIER, H. 1968. Der Brief an die Epheser. Düsseldorf : Ruprecht.

SCHNACKENBURG, R. 1982. Der grosse Eulogie Eph. 1, 3-14: Analyse unter textlinguistischen Aspekten. Biblische Zeitschrift, 27(21):67-87.

SMITH, G.V. 1975. Paul's use of Psalm 68 in Ephesians 4. Journal of the Evangelical Theological Society, 18:181-189.

STRACK, H.L. \& BILLERBECK, P. 1927. Kommentar zum Neuen Testament aus Talmud und Midrasch. Band III. München : Beck. 
TAYLOR, R.A. 1991. The use of Psalm 68:18 in Ephesians 4:8 in the light of ancient versions. Bibliotheca Sacra, 148(39):319-336.

VAN DER PLOEG, J. 1971. Psalmen. Roermond : Romen \& Zonen.

VAN RENSBURG, F. 1989. Die Timoteus-himne (1 Tim. 3:16). (In Barkhuizen, J.H., red. Hymni Christiani. Hervormde Teologiese Studies, Supplementum 1. p. 8397.)

VAN 'T GOUDOEVER, J. 1969. The significance of the counting of the Omer. Assen : Van Gorcum.

VERSTEEG, J.P. 1971. Christus en de Geest. Kampen : Kok.

VERSTEEG, J.P. 1977. De oudtestamentische citaten in het nieuwe testament met name in het evangelie naar Mattheüs. In die Skriflig, 11(2):1-17.

VILJOEN, F.P. 1990. Die betekenis van psalmois, humnois en odais pneumatikais in Kolossense 3:16 en Efesiërs 5:18. Potchefstroom : PU vir CHO. (Th.D.-proefskrif.)

VILJOEN, F.P. 2001. Song and music in the Pauline epistles. Paul's utilisation of Jewish, Roman and Greek musical traditions to encourage the early Christian communities to praise God. In die Skriflig, 35(3):423-442.

VILJOEN, F.P. 2002. Die strategiese funksie van die Christus-himne in Kolossense 1:13-20. In die Skriflig, 36(1):67-89.

WALTER, D.M., ed. 1980. Liber Psalmorum, Vetus Testamentum Syriace, 2/3. Brill : Leiden.

WILSON, G.B. 1978. Ephesians. Edinburgh : The Banner of Truth.

WRIGHT, T. 1997. The original Jesus. Grand Rapids, Michigan : Eerdmans.

ZIMMERMANN, H. 1968. Neutestamentliche Methodenlehre. Darstellung der historisch-kritischen Metode. Stuttgart : Ruprecht.

\section{Kernbegrippe:}

intertekstualiteit

inter-Bybelse eksegese

lied en dogma

Psalm 68:18/19 en Efesiërs 4:8

\section{Key concepts:}

intertextuality inner-Biblical exegesis

Psalm 68:18/9 and Ephesians 4:8

song and dogma 
